\title{
Biological activity of Trichoderma spp. in greenhouse and in vitro studies
}

\section{Biologiczna aktywność Trichoderma spp. w badaniach szklarniowych oraz in vitro}

\author{
Altynai Mambaeva, Ilona Świerczyńska²*, Katarzyna Pieczul², Kenzhali Khidirov ${ }^{1}$ \\ Amankeldy Sadanov ${ }^{3}$, Olga Shemshura ${ }^{3}$, Bożena Łozowicka ${ }^{4}$
}

Summary

Study of the biological activity of Trichoderma included 4 isolates of T. asperelleum, T. harzianum, T. atroviride and plant pathogens: Fusarium avenaceum, F. culmorum, F. graminearum, F. poae, Oculimacula yallundae and Rhizoctonia cerealis. The cultures were grown as dual culture (pathogen/antagonist) under the laboratory conditions and the linear growth of the fungi was compared in the following days. In the greenhouse experiment, the influence of Trichoderma fungi on the mass of aboveground parts of maize, winter wheat and rapeseed was evaluated. Trichoderma isolates showed significant antagonistic activity to the pathogens tested in in vitro experiment. In both greenhouse tests, the beneficial effect of Trichoderma spp. was found on the mass of aboveground parts of plants in combination with wheat and oilseed rape. The results obtained in combination with maize showed no significant differences.

Key words: Trichoderma spp., biological activity, pathogens, antagonist

\section{Streszczenie}

W badaniach biologicznej aktywności grzybów rodzaju Trichoderma wykorzystano 4 izolaty T. asperellum, T. harzianum, T. atroviride oraz patogeny roślinne: Fusarium avenaceum, F. culmorum, F. graminearum, F. poae, Oculimacula yallundae i Rhizoctonia cerealis. W doświadczeniu laboratoryjnym prowadzono hodowlę bikultur (patogen/antagonista), porównując w kolejnych dniach wzrost liniowy grzybów. W części szklarniowej doświadczenia oceniano wpływ grzybów z rodzaju Trichoderma na masę części nadziemnej kukurydzy, pszenicy ozimej oraz rzepaku. W doświadczeniu in vitro izolaty Trichoderma wykazały istotne działanie antagonistyczne w stosunku do badanych patogenów. W obu wariantach testu szklarniowego stwierdzono korzystny wpływ Trichoderma spp. na masę części nadziemnej roślin w kombinacji z pszenicą i rzepakiem. Wyniki uzyskane w kombinacji z kukurydzą nie wykazały istotnych różnic.

Słowa kluczowe: Trichoderma spp., biologiczna aktywność, patogen, antagonista

\footnotetext{
${ }^{1}$ Kazachski Państwowy Uniwersytet Rolniczy, Aleja Abaya 8, Ałmaty, 050010, Kazachstan

${ }^{2}$ Instytut Ochrony Roślin - Państwowy Instytut Badawczy, Władysława Węgorka 20, 60-318 Poznań

${ }^{3}$ Instytut Mikrobiologii i Wirusologii, Bogenbaja Batyra 103, Ałmaty, 050010, Kazachstan

${ }^{4}$ Instytut Ochrony Roślin - Państwowy Instytut Badawczy, Terenowa Stacja Doświadczalna w Białymstoku

Chełmońskiego 22, 15-195 Białystok

*corresponding author: i.swierczynska@iorpib.poznan.pl
} 


\section{Wstęp / Introduction}

Grzyby z rodzaju Trichoderma należą do grupy mikroorganizmów odgrywających znaczącą rolę w środowisku naturalnym, występują powszechnie na całym świecie zasiedlając glebę i materię organiczną (Howell 2003). Wiele gatunków tego rodzaju, między innymi: Trichoderma asperellum, Trichoderma atroviride, Trichoderma hamatum, Trichoderma harzianum, Trichoderma koningi, Trichoderma virens, Trichoderma viride zalicza się do silnych antagonistów ograniczających rozwój wielu gatunków grzybów patogenicznych (Zafari i wsp. 2008; Piegza i wsp. 2009; Rajeswari i Kannabiran 2011; Gaikwad i wsp. 2018). Ich działanie przeciwko patogenom opiera się pośrednio na rywalizacji o składniki pokarmowe i przestrzeń do wzrostu oraz bezpośrednio poprzez wytwarzanie metabolitów antybiotycznych i mykopasożytnictwo (Howell 2003; Benitez i wsp. 2004; Wojtkowiak-Gębarowska 2006). Grzyby z rodzaju Trichoderma zasiedlające strefę ryzosfery mogą korzystnie wpływać na wzrost i rozwój roślin. Potwierdzają to wyniki licznych badań (Akladious i Abbas 2012; Hermosa i wsp. 2012; Zhang i wsp. 2013). Stymulacja wzrostu może odbywać się między innymi poprzez zwiększenie dostępności składników pokarmowych i ich przyswajalności przez rośliny (Altomare i wsp. 1999; Wojtkowiak-Gębarowska 2006; Shoresh i Harman 2008). Trichoderma spp. mogą także indukować odporność roślin oraz produkować związki stymulujące ich wzrost i rozwój (analogi hormonów roślinnych) (De Meyer i wsp. 1998; Benitez i wsp. 2004; Vinale i wsp. 2008a).

Mimo, że stosowanie środków chemicznych jest najprostszą metodą ochrony roślin uprawnych stale rośnie zainteresowanie biologicznymi metodami zwalczania chorób (Dubey i wsp. 2007). Preparaty ochrony roślin zawierające wyselekcjonowane szczepy mikroorganizmów są obiecującą alternatywą dla środków chemicznych (Monte 2001; Vinale i wsp. 2008b). Grzyby z rodzaju Trichoderma charakteryzują się wysoką aktywnością fizjologiczną oraz zdolnością do hamowania wzrostu wielu gatunków grzybów patogenicznych, co sprawia że znajdują się w składzie wielu biologicznych środków ochrony roślin (Nosir 2016; Kumar i wsp. 2017; Mambaeva i wsp. 2018). Niektóre gatunki z rodzaju Trichoderma są również wykorzystywane w różnych gałęziach przemysłu, głównie w produkcji enzymów, antybiotyków i innych metabolitów. Wśród grzybów z rodzaju Trichoderma wyróżniamy gatunki chorobotwórcze dla ludzi i zwierząt (Błaszczyk i wsp. 2014).

\section{Materiały i metody / Materials and methods}

W badaniu laboratoryjnym wykorzystano 6 izolatów antagonistycznego grzyba Trichoderma: T. harzianum i T. atroviride pochodzące z kolekcji Zakładu Mykologii
Instytutu Ochrony Roślin - Państwowego Instytutu Badawczego oraz 4 izolaty T. asperellum (T.a. 10, T.a. 30, T.a. AHT, T.a. M) pochodzące z kolekcji Instytutu Mikrobiologii i Wirusologii w Ałmatach w Kazachstanie oraz 6 kultur grzybów patogenicznych: Fusarium avenaceum, Fusarium culmorum, Fusarium graminearum, Fusarium poae, Oculimacula yallundae i Rhizoctonia cerealis wyizolowanych z pszenicy w Zakładzie Mykologii Instytutu Ochrony Roślin - Państwowego Instytutu Badawczego w Poznaniu.

Identyfikacja gatunkowa poszczególnych izolatów została potwierdzona na podstawie wyników analizy sekwencji rybosomalnego DNA. Genomowy DNA testowanych izolatów wyizolowano ze świeżej grzybni, hodowanej w temperaturze pokojowej przez 10 dni na pożywce stałej PDA (Potato Dextrose Agar, Oxoid). Grzybnię zeskrobano z pożywki za pomocą sterylnego skalpela i roztarto w moździerzu z dodatkiem sterylnego piasku kwarcowego. Izolację DNA przeprowadzono przy użyciu Plant Fungi DNA Isolation Kit (Norgen Biotek) zgodnie z protokołem producenta. W reakcji PCR (polymerase chain reaction) zastosowano startery ITS 1 i ITS 5 (White i wsp. 1990). Ostateczna objętość reakcji wynosząca 12,5 $\mu \mathrm{l}$ zawierała: $0,2 \mu \mathrm{l} 10 \mu \mathrm{M}$ starterów ITS 5 i ITS 4, 1,25 $\mu$ 1 10-krotnego buforu Dream Tag (Thermo Fisher Scientific), 0,25 $\mu \mathrm{l} 200 \mu \mathrm{M}$ mieszaniny dNTP (Thermo Fisher Scientific), 0,05 $\mu 15$ U Dream Taq DNA polimerazy (Thermo Fisher Scientific), 1,5 $\mu 1$ roztworu DNA o stężeniu $30 \mathrm{ng} / \mathrm{h}$ oraz $9,25 \mu \mathrm{l}$ sterylnej wody destylowanej. Zastosowano następujący profil termiczny reakcji PCR: początkowa denaturacja przez 4 min w $95^{\circ} \mathrm{C}$; 39 cykli złożonych z: denaturacji $40 \mathrm{~s} \mathrm{w} 94^{\circ} \mathrm{C}$, hybrydyzacji starterów $40 \mathrm{~s} \mathrm{w} 53^{\circ} \mathrm{C}$, elongacji $90 \mathrm{~s} \mathrm{w} 72^{\circ} \mathrm{C}$; ostateczna elongacja -5 min w temperaturze $72^{\circ} \mathrm{C}$. Rozdział elektroforetyczny przeprowadzono w buforze $1 \mathrm{x}$ TBE przy $60 \mathrm{~V}$ w 2\% żelu agarozowym (Basica LE GQT, Pronat) zabarwionym Midori Green (Nippon). Fragment DNA kodujący $600 \mathrm{pz}$ poddano analizie sekwencyjnej (dideoksy Sanger). Analizę wyników sekwencjonowania przeprowadzono w programie MEGA 6.

Testowane grzyby wyszczepiano parami (patogen /antagonista) na przygotowaną wcześniej pożywkę PDA na płytkach Petriego $90 \mathrm{~mm}$. W tym celu wycięte korkoborem krążki $(5 \mathrm{~mm}) \mathrm{z}$ inokulum odpowiedniego grzyba przenoszono, umieszczając je po przeciwnych stronach płytki Petriego w odległości około $5 \mathrm{~mm}$ od brzegu. W kombinacji kontrolnej wyszczepiano poszczególne grzyby pojedynczo. Hodowlę prowadzono w temperaturze $21^{\circ} \mathrm{C}$. Co dwa dni od momentu inokulacji mierzono promienie kolonii grzybów, porównując wzrost liniowy pojedynczych kultur na płytkach kontrolnych ze wzrostem liniowym kolonii w bikulturach. W każdej kombinacji zastosowano 3 powtórzenia. Do analizy wykorzystano pomiary wykonane po 10 dniach. Wyniki uzyskane w doświadczeniu opracowano statystycznie za pomocą analizy wariancji 
dwuczynnikowej przy użyciu testu Duncana, na poziomie istotności $\alpha=0,05$.

Doświadczenie szklarniowe przeprowadzono w dwóch wariantach z wykorzystaniem 3 gatunków roślin uprawnych: kukurydzy, pszenicy ozimej i rzepaku oraz 3 gatunków antagonistycznego grzyba Trichoderma: T. asperellum (izolat T.a. 30), T. harzianum oraz T. atroviride. Rośliny wysiewano do donic wypełnionych ziemią do wysiewu i pikowania Kronen w ilościach po 25 (pszenica, rzepak) lub 15 (kukurydza) sztuk nasion na donicę. Użyte w doświadczeniu grzyby z rodzaju Trichoderma zastosowano w formie zawiesiny, którą otrzymano przez spłukiwanie wodą destylowaną zarodników wraz z grzybnią powierzchniową z wyhodowanych wcześniej tygodniowych kultur. Otrzymane zawiesiny rozcieńczano do uzyskania stężenia zarodników na poziomie $10^{8} / \mathrm{ml}$. W wariancie pierwszym, nasiona wykorzystanych $\mathrm{w}$ doświadczeniu roślin zaprawiano zawiesiną zarodników poszczególnych gatunków Trichoderma spp. W tym celu moczono nasiona przez 10 minut w zawiesinie zarodników i następnie wysiewano do donic. W wariancie drugim, rośliny wysiewano i po upływie tygodnia za pomocą pipety podlewano każdą siewkę zawiesiną zarodników Trichoderma spp. w ilości 1,5 ml na roślinę. Dla każdej kombinacji zastosowano 3 powtórzenia. Doświadczenie szklarniowe w obu wariantach prowadzono $\mathrm{w}$ temperaturze $25^{\circ} \mathrm{C}$ utrzymując przez cały czas wyrównane warunki wilgotnościowe. Po upływie 4 tygodni wzrostu dokonano oceny doświadczenia. Oddzielono część nadziemną badanych roślin i zważono. Uzyskane wyniki opracowano statystycznie za pomocą analizy wariancji dwuczynnikowej przy użyciu testu Duncana, na poziomie istotności $\alpha=0,05$.

\section{Wyniki i dyskusja / Results and discussion}

Oznaczenia taksonomiczne wszystkich badanych izolatów zostały potwierdzone na podstawie analizy sekwencji rybosomalnego DNA (rejon ITS 1 - 5,8 rDNA - ITS2).

Badane izolaty Trichoderma charakteryzowały się szybkim tempem wzrostu. Po 10 dniach od momentu założenia doświadczenia grzybnie pokrywały całą powierzchnię płytek Petriego zarówno w bikulturach, jak i monokulturach (próby kontrolne). Wolniejszym tempem wzrostu wykazał się tylko jeden izolat T. asperellum (T.a. AHT) (tab. 1). Jest to istotna cecha ze względu na możliwość konkurencji o przestrzeń do wzrostu badanych szczepów Trichoderma z koloniami patogenów (Popiel i wsp. 2008). W bikulturach grzybnie patogenów rozwijały się do momentu zetknięcia z grzybnią antagonisty lub do momentu zbliżenia obu grzybni i wytworzenia strefy hamowania (tab. 2). Po 10 dniach hodowli izolaty T. asperellum (T.a. 1M, T.a. 10 oraz T.a. 30) całkowicie porosły grzybnię wszystkich patogenów silnie ograniczając ich wzrost. Najmniej inwazyjny okazał się izolat T.a. AHT. Wolny wzrost grzybni tego izolatu pozwolił na szybszy przyrost kolonii grzybów patogenicznych, jednak znacznie mniejszy w porównaniu z kontrolą w monokulturach. Izolaty T. harzianum i T. atroviride po 10 dniach inkubacji porosły całą powierzchnię pożywki do granicy z kolonią patogena lub zostawiając niewielką strefę hamowania. Szybko rosnący $R$. cerealis był jednocześnie najmniej odporny na agresywne działanie T. harzianum i T. atroviride, gdyż jako jedyny patogen w bikulturach z tymi antagonistami został przez nie porośnięty (tab. 1, 2). Skuteczne ograniczanie wzrostu i zarastanie grzybni patogenów przez Trichoderma spp. w bikulturach potwierdza-

Tabela 1. Promień grzybni Trichoderma spp. w bikulturze z patogenem [mm] Table 1. Mycelium radius of Trichoderma spp. in bicultures with pathogen [mm]

\begin{tabular}{l|c|c|c|c|c|c}
\hline \multicolumn{1}{c}{$\begin{array}{c}\text { Gatunek grzyba } \\
\text { Species of fungus }\end{array}$} & $\begin{array}{c}\text { Trichoderma } \\
\text { asperellum } \\
10\end{array}$ & $\begin{array}{c}\text { Trichoderma } \\
\text { asperellum } \\
30\end{array}$ & $\begin{array}{c}\text { Trichoderma } \\
\text { asperellum } \\
1 \mathrm{M}\end{array}$ & $\begin{array}{c}\text { Trichoderma } \\
\text { asperellum } \\
\text { AHT }\end{array}$ & $\begin{array}{c}\text { Trichoderma } \\
\text { harzianum }\end{array}$ & $\begin{array}{c}\text { Trichoderma } \\
\text { atroviride }\end{array}$ \\
\hline $\begin{array}{l}\text { Fusarium } \\
\text { avenaceum }\end{array}$ & $75,00 \mathrm{e}$ & $75,00 \mathrm{e}$ & $75,00 \mathrm{e}$ & $44,00 \mathrm{bc}$ & $75,00 \mathrm{e}$ & $75,00 \mathrm{e}$ \\
\hline $\begin{array}{l}\text { Fusarium } \\
\text { culmorum }\end{array}$ & $75,00 \mathrm{e}$ & $75,00 \mathrm{e}$ & $75,00 \mathrm{e}$ & $38,33 \mathrm{a}$ & $75,00 \mathrm{e}$ & $75,00 \mathrm{e}$ \\
\hline $\begin{array}{l}\text { Fusarium } \\
\text { graminearum }\end{array}$ & $75,00 \mathrm{e}$ & $75,00 \mathrm{e}$ & $75,00 \mathrm{e}$ & $47,33 \mathrm{~cd}$ & $75,00 \mathrm{e}$ & $75,00 \mathrm{e}$ \\
\hline $\begin{array}{l}\text { Fusarium } \\
\text { poae }\end{array}$ & $75,00 \mathrm{e}$ & $75,00 \mathrm{e}$ & $75,00 \mathrm{e}$ & $40,33 \mathrm{ab}$ & $75,00 \mathrm{e}$ & $75,00 \mathrm{e}$ \\
\hline $\begin{array}{l}\text { Oculimacula } \\
\text { yallundae }\end{array}$ & $75,00 \mathrm{e}$ & $75,00 \mathrm{e}$ & $75,00 \mathrm{e}$ & $50,00 \mathrm{~d}$ & $75,00 \mathrm{e}$ & $75,00 \mathrm{e}$ \\
\hline $\begin{array}{l}\text { Rhizoctonia } \\
\text { cerealis }\end{array}$ & $75,00 \mathrm{e}$ & $75,00 \mathrm{e}$ & $75,00 \mathrm{e}$ & $46,33 \mathrm{~cd}$ & $75,00 \mathrm{e}$ & $75,00 \mathrm{e}$ \\
\hline $\begin{array}{l}\text { Kontrola } \\
\text { Control }\end{array}$ & $75,00 \mathrm{e}$ & $75,00 \mathrm{e}$ & $40,00 \mathrm{ab}$ & $75,00 \mathrm{e}$ & $75,00 \mathrm{e}$ \\
\hline
\end{tabular}

Średnie oznaczone tymi samymi literami nie różnią się istotnie przy poziomie $\alpha=0,05$

Mean values marked with the same letters were not statistically significant $\alpha=0.05$ 
Tabela 2. Promień grzybni patogena w bikulturze z Trichoderma spp. [mm] Table 2. Mycelium radius of pathogen in bicultures with Trichoderma spp. [mm]

\begin{tabular}{l|c|c|c|c|c|c}
\hline $\begin{array}{c}\text { Gatunek grzyba } \\
\text { Species of fungus }\end{array}$ & $\begin{array}{c}\text { Fusarium } \\
\text { avenaceum }\end{array}$ & $\begin{array}{c}\text { Fusarium } \\
\text { culmorum }\end{array}$ & $\begin{array}{c}\text { Fusarium } \\
\text { graminearum }\end{array}$ & $\begin{array}{c}\text { Fusarium } \\
\text { poae }\end{array}$ & $\begin{array}{c}\text { Oculimacula } \\
\text { yallundae }\end{array}$ & $\begin{array}{c}\text { Rhizoctonia } \\
\text { cerealis }\end{array}$ \\
\hline $\begin{array}{c}\text { Trichoderma } \\
\text { asperellum } 10\end{array}$ & $1,67 \mathrm{a}-\mathrm{c}$ & $3,00 \mathrm{a}-\mathrm{e}$ & $1,00 \mathrm{ab}$ & $6,67 \mathrm{~d}-\mathrm{g}$ & $0,00 \mathrm{a}$ & $21,67 \mathrm{j}$ \\
\hline $\begin{array}{l}\text { Trichoderma } \\
\text { asperellum } 30\end{array}$ & $2,33 \mathrm{a}-\mathrm{d}$ & $1,67 \mathrm{a}-\mathrm{c}$ & $1,67 \mathrm{a}-\mathrm{c}$ & $6,67 \mathrm{~d}-\mathrm{g}$ & $0,00 \mathrm{a}$ & $20,33 \mathrm{j}$ \\
\hline $\begin{array}{l}\text { Trichoderma } \\
\text { asperellum } 1 \mathrm{M}\end{array}$ & $4,00 \mathrm{a}-\mathrm{f}$ & $8,00 \mathrm{fg}$ & $2,67 \mathrm{a}-\mathrm{d}$ & $8,33 \mathrm{fg}$ & $0,00 \mathrm{a}$ & $19,33 \mathrm{ij}$ \\
\hline $\begin{array}{l}\text { Trichoderma } \\
\text { asperellum AHT }\end{array}$ & $6,00 \mathrm{c}-\mathrm{g}$ & $18,00 \mathrm{~h}-\mathrm{j}$ & $9,67 \mathrm{~g}$ & $14,67 \mathrm{~h}$ & $1,67 \mathrm{a}-\mathrm{c}$ & $31,00 \mathrm{k}$ \\
\hline $\begin{array}{l}\text { Trichoderma } \\
\text { harzianum }\end{array}$ & $2,00 \mathrm{a}-\mathrm{d}$ & $8,33 \mathrm{fg}$ & $5,67 \mathrm{~b}-\mathrm{g}$ & $8,67 \mathrm{fg}$ & $0,00 \mathrm{a}$ & $18,00 \mathrm{~h}-\mathrm{j}$ \\
\hline $\begin{array}{l}\text { Trichoderma } \\
\text { atroviride }\end{array}$ & $2,67 \mathrm{a}-\mathrm{d}$ & $15,33 \mathrm{hi}$ & $3,00 \mathrm{a}-\mathrm{e}$ & $7,67 \mathrm{e}-\mathrm{g}$ & $0,00 \mathrm{a}$ & $19,67 \mathrm{ij}$ \\
\hline $\begin{array}{l}\text { Kontrola } \\
\text { Control }\end{array}$ & $10,33 \mathrm{~g}$ & $68,67 \mathrm{~m}$ & $31,33 \mathrm{k}$ & 44,001 & $2,00 \mathrm{a}-\mathrm{d}$ & $75,00 \mathrm{n}$ \\
\hline
\end{tabular}

Średnie oznaczone tymi samymi literami nie różnią się istotnie przy poziomie $\alpha=0,05$

Mean values marked with the same letters were not statistically significant $\alpha=0.05$

ją prace innych autorów (Zafari i wsp. 2008; Piegza i wsp. 2009; Rajeswari i Kannabiran 2011; Gaikwad i wsp. 2018). Izolaty Trichoderma spp. mogą różnić się jednak stopniem ograniczania wzrostu tego samego patogena (Popiel i wsp. 2008; El-Komy i wsp. 2015). W badaniach szczepów T. asperellum i T. album wyizolowanych z ryzosfery roślin warzywnych wykazano wyższą aktywność antybiotyczną, jak i mykopasożytniczą T. asperellum (Mambaeva i wsp. 2018). Ommati i Zaker (2012) stwierdzili hamującą aktywność szczepów Trichoderma brevicompactum, Trichoderma asperellum i Trichoderma longibrachiatum na wzrost Fusarium sp. - patogena ziemniaka. Antagonistyczna aktywność izolatów Trichoderma została również potwierdzona przeciwko szarej pleśni wywołanej przez grzyb Botrytis cinerea, który jest patogenem wielu upraw (Bogumił i wsp. 2013).

Podczas makroskopowej oceny kondycji roślin nie odnotowano objawów chorobowych na podstawach łodyg i korzeniach zarówno roślin kontrolnych, jak i traktowanych Trichoderma spp. Na podstawie przeprowadzonych badań stwierdzono korzystny wpływ Trichoderma spp. na masę liści pszenicy. Średnia masa 25 roślin wyrosłych z nasion zaprawianych wcześniej zawiesiną zarodników T. asperellum (T.a. 30) i T. atroviride była większa niż w kontroli odpowiednio o 3,10 i 2,43 g (tab. 3). Podlewanie zawiesiną zarodników, tygodniowych siewek pszenicy, pozwoliło uzyskać większą masę części nadziemnej w przypadku T. harzianum i T. atroviride - odpowiednio o 3,03 i 2,40 g większą niż w próbie kontrolnej (tab. 3). Pozytywny wpływ T. harzianum na parametry wzrostu siewek pszenicy w warunkach kontrolnych oraz w warunkach zasolenia podłoża stwierdził Rawat i wsp. (2011) oraz Zhang i wsp. (2013, 2016) badając w podobnych warunkach $T$. longibrachiatum. Również inni badacze stwierdzili korzystny wpływ Trichoderma spp. na suchą masę siewek pszenicy (Shivanna i wsp. 1996; Zafari i wsp. 2008). Donoso i wsp. (2008) zaobser- wowali pozytywny wpływ T. harzianum na wielkość suchej masy pszenicy w warunkach deficytu wody.

Badania rzepaku wykazały wyraźnie korzystny wpływ T. asperellum (T.a. 30) na otrzymaną masę części nadziemnej roślin. W próbie, w której podlewano tygodniowe siewki zawiesiną zarodników uzyskano średnią masę 25 roślin większą o 6,93 g niż w kontroli. Jednak zaprawianie nasion rzepaku zawiesiną zarodników T. asperellum T.a. 30 nie przyczyniło się do zwiększenia masy roślin. Wyniki traktowania nasion/siewek rzepaku zawiesiną zarodników pozostałych gatunków Trichoderma nie różniły się istotnie w porównaniu z próbą kontrolną (tab. 3). W badaniach Maag i wsp. (2014) stwierdzono pozytywny wpływ T. atroviride na parametry wzrostu roślin rzepaku ozimego. Obserwowany był także korzystny wpływ niektórych metabolitów wtórnych Trichoderma spp. na wzrost roślin rzepaku (Vinale i wsp. 2008a).

W badaniach Sankar i Sharma (2001) zaobserwowano poprawę wszystkich danych biometrycznych i składników plonu kukurydzy po uprzednim traktowaniu nasion T. viride. Podobnie w badaniach Akladious i Abbas (2012), zastosowanie T. harzianum poprzez wprowadzenie do gleby lub zaprawianie nasion kukurydzy przyczyniło się do wzrostu wszystkich mierzonych parametrów. W niniejszym doświadczeniu w obu wariantach nie zaobserwowano korzystnego wpływu badanych gatunków Trichoderma na masę roślin kukurydzy (tab. 3). Również Abd El-Hamed i wsp. (2011) badając wpływ Trichoderma spp. na procent kiełkowania nasion kukurydzy nie stwierdzili istotnej różnicy między próbą doświadczalną a kontrolną. W badaniu Mao i wsp. (1997), siewki kukurydzy wyrosłe z nasion traktowanych uprzednio $T$. viride i wysiewanych do niezainfekowanej gleby, nie wykazały większej masy i wysokości niż siewki w próbie kontrolnej. Podobnie Macek i Celar (1990) stwierdzili, że traktowanie nasion kukurydzy T. longibra- 
Tabela 3. Średnia waga 25 roślin traktowanych zawiesiną Trichoderma spp. w dwóch wariantach [g] Table 3. The average weight of 25 plants treated with Trichoderma spp. suspension in two variants [g]

\begin{tabular}{|c|c|c|c|}
\hline $\begin{array}{l}\text { Antagonista } \\
\text { Antagonist }\end{array}$ & $\begin{array}{c}\text { Zaprawianie } \\
\text { Seed treatment }\end{array}$ & $\begin{array}{l}\text { Podlewanie } \\
\text { Sprinkling }\end{array}$ & $\begin{array}{c}\text { Kontrola } \\
\text { Control }\end{array}$ \\
\hline \multicolumn{4}{|c|}{ Kukurydza - Maize } \\
\hline Trichoderma asperellum T.a. 30 & $84,20 \mathrm{a}$ & $76,40 \mathrm{a}$ & \\
\hline Trichoderma harzianum & $79,00 \mathrm{a}$ & $78,43 \mathrm{a}$ & $87,37 \mathrm{a}$ \\
\hline Trichoderma atroviride & 83,93 a & $79,10 \mathrm{a}$ & \\
\hline \multicolumn{4}{|c|}{ Pszenica - Wheat } \\
\hline Trichoderma asperellum T.a. 30 & $21,30 \mathrm{~b}$ & $19,63 \mathrm{ab}$ & \\
\hline Trichoderma harzianum & $20,40 \mathrm{ab}$ & $21,23 \mathrm{~b}$ & $18,20 \mathrm{a}$ \\
\hline Trichoderma atroviride & $20,63 \mathrm{~b}$ & $20,60 \mathrm{~b}$ & \\
\hline \multicolumn{4}{|c|}{ Rzepak - Oilseed rape } \\
\hline Trichoderma asperellum T.a. 30 & $27,00 \mathrm{a}$ & $34,70 \mathrm{~b}$ & \\
\hline Trichoderma harzianum & $30,83 \mathrm{ab}$ & $31,53 \mathrm{ab}$ & $27,77 \mathrm{a}$ \\
\hline Trichoderma atroviride & $28,97 \mathrm{ab}$ & $29,57 \mathrm{ab}$ & \\
\hline
\end{tabular}

Średnie oznaczone w rzędach tymi samymi literami nie różnią się istotnie przy poziomie $\alpha=0,05$

Mean values marked in rows with the same letters were not statistically significant $\alpha=0.05$

chiatum nie miało jednolitego wpływu na zieloną masę i wysokość roślin.

\section{Wnioski / Conclusions}

1. Izolaty Trichoderma zastosowane w doświadczeniu laboratoryjnym wykazały antagonistyczne działanie w stosunku do badanych patogenów.
2. Najsilniejsze właściwości mykopasożytnicze odnotowano dla 3 szczepów T. asperellum.

3. Odnotowany został korzystny wpływ zaprawiania nasion Trichoderma spp. na zieloną masę pszenicy i rzepa$\mathrm{ku}$.

\section{Literatura / References}

Abd El-Hamed K.E., Elwan M.W.M., Shaban W.I. 2011. Enhanced sweet corn propagation: studies on transplanting feasibility and seed priming. Vegetable Crops Research Bulletin 75 (1): 31-50. DOI: 10.2478/v10032-011-0016-4.

Akladious S.A., Abbas S.M. 2012. Application of Trichoderma harziunum T22 as a biofertilizer supporting maize growth. African Journal of Biotechnology 11 (35): 8672-8683. DOI: 10.5897/AJB11.4323.

Altomare C., Norvell W.A., Björkman T., Harman G.E. 1999. Solubilization of phosphates and micronutrients by the plant-growth-promoting and biocontrol fungus Trichoderma harzianum Rifai 1295-22. Applied and Environmental Microbiology 65 (7): 2926 -2933.

Benítez T., Rincón A.M., Limón M.C., Codón A.C. 2004. Biocontrol mechanisms of Trichoderma strains. International Microbiology 7 (4): 249-260.

Błaszczyk L., Siwulski M., Sobieralski K., Lisiecka J., Jędryczka M. 2014. Trichoderma spp. - application and prospects for use in organic farming and industry. Journal of Plant Protection Research 54 (4): 309-317. DOI: 10.2478/jppr-2014-0047.

Bogumił A., Paszt L.S., Lisek A., Trzciński P., Harbuzov A. 2013. Identification of new Trichoderma strains with antagonistic activity against Botrytis cinerea. [Identyfikacja nowych szczepów Trichoderma o aktywności antagonistycznej przeciwko Botrytis cinerea]. Folia Horticulturae 25 (2): 123-132. DOI: 10.2478/fhort-2013-0014.

De Meyer G., Bigirimana J., Elad Y., Höfte M. 1998. Induced systemic resistance in Trichoderma harzianum T39 biocontrol of Botrytis cinerea. European Journal of Plant Pathology 104 (3): 279-286. DOI: 10.1023/A:1008628806616.

Donoso E.P., Bustamante R.O., Carú M., Niemeyer H.M. 2008. Water deficit as a driver of the mutualistic relationship between the fungus Trichoderma harzianum and two wheat genotypes. Applied and Environmental Microbiology 74 (5): 1412-1417. DOI: 10.1128/ AEM.02013-07.

Dubey S.C., Suresh M., Singh B. 2007. Evaluation of Trichoderma species against Fusarium oxysporum f. sp. ciceris for integrated management of chickpea wilt. Biological Control 40 (1): 118-127. DOI: 10.1016/j.biocontrol.2006.06.006. 
El-Komy M.H., Saleh A.A., Eranthodi A., Molan Y.Y. 2015. Characterization of novel Trichoderma asperellum isolates to select effective biocontrol agents against tomato Fusarium wilt. Plant Pathology Journal 31 (1): 50-60. DOI: 10.5423/PPJ.OA.09.2014.0087.

Gaikwad S.N., Salve S.N., Rajurkar S.K. 2018. In vitro antagonistic activity of Trichoderma harzianum against soilborne fungal pathogens. International Journal of Biology Research 3 (2): 87-89.

Hermosa R., Viterbo A., Chet I., Monte E. 2012. Plant-beneficial effects of Trichoderma and of its genes. Microbiology 158 (1): 17-25. DOI: 10.1099/mic.0.052274-0.

Howell C.R. 2003. Mechanisms employed by Trichoderma species in the biological control of plant diseases: The history and evolution of current concepts. Plant Disease 87 (1): 4-10. DOI: 10.1094/PDIS.2003.87.1.4.

Kumar G., Maharshi A., Patel J., Mukherjee A., Singh H.B., Sarma B.K. 2017. Trichoderma: a potential fungal antagonist to control plant diseases. Annual Technical Issue 21: 206-218.

Maag D., Kandula D.R.W., Müller C., Mendoza-Mendoza A., Wratten S.D., Stewart A., Rostás M. 2014. Trichoderma atroviride LU132 promotes plant growth but not induced systemic resistance to Plutella xylostella in oilseed rape. BioControl 59 (2): 241-252. DOI: 10.1007/s10526-013-9554-7.

Maček J., Celar F. 1990. Physiological properties of the fungus Trichoderma longibrachiatum Rifai and its pathogenicity for maize seedlings and young maize plants. Journal of Phytopathology 130 (3): 241-248. DOI: 10.1111/j.1439-0434.1990.tb01173.x.

Mambaeva A., Sadanov A., Shemshura O., Ibishev U., Alimzhanova M., Lozovicka B. 2018. Prospects of using fungi of genus Trichoderma as agents of biocontrol for fungal diseases of potatoes and cucumbers in Kazakhstan. Journal of Pharmaceutical Sciences and Research 10 (11): 2855-2857.

Mao W., Lewis J.A., Hebbar P.K., Lumsden R.D. 1997. Seed treatment with a fungal or a bacterial antagonist for reducing corn dampingoff caused by species of Pythium and Fusarium. Plant Disease 81 (5): 450-454. DOI: 10.1094/PDIS.1997.81.5.450.

Monte E. 2001. Understanding Trichoderma: between biotechnology and microbial ecology. International Microbiology 4: 1-4. DOI: $10.1007 / \mathrm{s} 101230100001$

Nosir W.S. 2016. Trichoderma harzianum as a growth promoter and bio-control agent against Fusarium oxysporum f. sp. tuberosi. Advances in Crop Science and Technology 4 (2): 217. DOI: 10.4172/2329-8863.1000217.

Ommati F., Zaker M. 2012. In vitro and greenhouse evaluations of Trichoderma isolates for biological control of potato wilt disease (Fusarium solani). Archives of Phytopathology and Plant Protection 45 (14): 1715-1723. DOI: 10.1080/03235408.2012.702467.

Piegza M., Stolaś J., Kancelista A., Witkowska D. 2009. Wpływ grzybów rodzaju Trichoderma na wzrost patogennych grzybów strzępkowych w testach biotycznych na nietypowych źródłach węgla. [Influence of Trichoderma strains on the growth of pathogenic moulds in biotic test on untypical carbon sources]. Acta Scientiarum Polonorum, Biotechnologia 8 (1): 3-14.

Popiel D., Kwaśna H., Chełkowski J., Stępień Ł., Laskowska M. 2008. Impact of selected antagonistic fungi on Fusarium species - toxigenic cereal pathogens. [Antagonistyczne oddziaływanie wybranych grzybów na toksynotwórcze gatunki Fusarium patogeniczne dla zbóż]. Acta Mycologica 43 (1): 29-40.

Rajeswari P., Kannabiran B. 2011. In vitro effects of antagonistic microorganisms on Fusarium oxysporum [Schlecht. Emend. Synd \& Hans] infecting Arachis hypogaea L. Journal of Phytology 3 (3): 83-85.

Rawat L., Singh Y., Shukla N., Kumar J. 2011. Alleviation of the adverse effects of salinity stress in wheat (Triticum aestivum L.) by seed biopriming with salinity tolerant isolates of Trichoderma harzianum. Plant and Soil 347: 387-400. DOI: 10.1007/s11104-0110858-z.

Sankar P., Sharma R.C. 2001. Management of charcoal rot of maize with Trichoderma viride. Indian Phytopathology 54 (3): 390-391.

Shivanna M.B., Meera M.S., Kageyama K., Hyakumachi M. 1996. Growth promotion ability of zoysiagrass rhizosphere fungi in consecutive plantings of wheat and soybean. Mycoscience 37 (2): 163-168. DOI: 10.1007/BF02461341.

Shoresh M., Harman G.E. 2008. The molecular basis of shoot responses of maize seedlings to Trichoderma harzianum T22 inoculation of the root: a proteomic approach. Plant Physiology 147 (4): 2147-2163. DOI: 10.1104/pp.108.123810.

Vinale F., Sivasithamparam K., Ghisalberti E.L., Marra R., Barbetti M.J., Li H., Woo S.L., Lorito M. 2008a. A novel role for Trichoderma secondary metabolites in the interactions with plants. Physiological and Molecular Plant Pathology 72 (1-3): 80-86. DOI: 10.1016/j. pmpp.2008.05.005.

Vinale F., Sivasithamparam K., Ghisalberti E.L., Marra R., Woo S.L., Lorito M. 2008b. Trichoderma-plant-pathogen interactions. Soil Biology and Biochemistry 40 (1): 1-10. DOI: 10.1016/j.soilbio.2007.07.002.

White T.J., Bruns T.D., Lee S.B., Taylor J.W. 1990. Amplification and direct sequencing of fungal ribosomal RNA genes for phylogenetics. s. 315-322. W: PCR Protocols: A Guide to Methods and Applications (M.A. Innis, D.H. Gelfand, J.J. Sninsky, T.J. White, red.). Academic Press, New York. DOI: 10.1016/B978-0-12-372180-8.50042-1.

Wojtkowiak-Gębarowska E. 2006. Mechanizmy zwalczania fitopatogenów glebowych przez grzyby z rodzaju Trichoderma. Postępy Mikrobiologii 45 (4): 261-273.

Zafari D., Koushki M.M., Bazgir E. 2008. Biocontrol evaluation of wheat take-all disease by Trichoderma screened isolates. African Journal of Biotechnology 7 (20): 3653-3659.

Zhang S., Gan Y., Xu B. 2016. Application of plant-growth-promoting fungi Trichoderma longibrachiatum T6 enhances tolerance of wheat to salt stress through improvement of antioxidative defense system and gene expression. Frontiers in Plant Science 7: 1405. DOI: $10.3389 /$ fpls.2016.01405.

Zhang F., Yuan J., Yang X., Cui Y., Chen L., Ran W., Shen Q. 2013. Putative Trichoderma harzianum mutant promotes cucumber growth by enhanced production of indole acetic acid and plant colonization. Plant Soil 368 (1-2): 433-444. DOI: 10.1007/s11104-012$1519-6$. 